\title{
THE FINANCIAL IMPACT OF URBANIZATION COSTS IN POLAND AT MUNICIPALITY LEVEL - THE CASE OF WROCEAW CITY
}

\author{
Heldak Maria, Przybyla Katarzyna \\ Wrocław University of Environmental and Life Sciences (Poland) \\ Faculty of Environmental and Engineering and Geodesy \\ Department of Spatial Economy
}

\begin{abstract}
The study discusses the problem of financial impact on Wrocław Municipality exerted by the costs of implementing decisions resulting from the selected local spatial development plans. Currently in Poland, at the stage of local spatial development plan establishment, a forecast of financial consequences is prepared. The expected own revenues and the costs of financial impact exerted on the municipal budget are presented in this document. The study facilitates making decisions about the final version of the local development plan. Taking into account the planned spatial development in the area of Wrocław city, the urbanization costs exerting financial impact on the municipal budget were identified. The study analyses only the cost of implementing investments within the scope of the municipality own tasks, including the cost of constructing municipal roads, sanitary sewerage system, water supply system, public greenery facilities and land purchase for public investments. The analyses covered two selected areas of the city, located in its different parts. These are largely uninvested areas, predominantly constituting agricultural land, and such land development requires the construction of technical and social infrastructure facilities. The anticipated costs of implementing local development plans in force in various parts of Wrocław indicate significant expenses to be covered by Wrocław Municipality in order to build sewage systems and municipal roads. Taking up new development sites is also correlated with taking over the real properties by Wrocław city, on which the implementation of public goals is planned.
\end{abstract}

Key words: financial effects, urbanization, local development, plan, implementation

\section{Introduction}

Currently, in Poland, space development is based on the local spatial development plan, and in the case of its absence - pursuant to the decision on land development conditions. The spatial policy defined in the document of municipal conditions and directions for spatial development provides the basis for determining functions in the local development plan, and next for the implementation of investments (Hełdak and Raszka, 2013; Hełdak et al., 2016).

When such local spatial development plan becomes binding, it results in economic implications. In Poland, these consequences are specified in the forecast of the financial impact. It estimates own revenues as well as the costs incurred by the municipal budget with respect to the implementation of municipal tasks. In turn, the access to technological infrastructure facilities, in particular to cultural, educational and sports services influences the quality of life of local residents (Przybyła et al., 2014; Hełdak and Płuciennik 2017).

The identification of municipal financial impact results from the provisions of the Local Government Act (The Act dated March 8, 1990, on Municipal Self-Government), in which the legislator provides the catalogue of tasks to be implemented by the municipal authorities. It allows verifying the economic rationality of the local development plan draft and adjusting the adopted planning solutions before the plan is approved, thus reducing municipal expenses, which result from the adoption of the plan. Pursuant to the Act, the municipality own tasks include satisfying collective needs of the community, covering e.g. the most frequently estimated, in the financial impact forecast, own tasks including: real property management, municipal roads, streets, bridges, squares and road traffic organization, waterworks and water supply issues, sewerage system, municipal wastewater removal and treatment, maintenance of cleanliness and order as well as sanitation facilities, landfills and municipal waste disposal, local public transport, physical culture and tourism also including recreational areas and sport facilities, municipal greenery, tree stands, and municipal cemeteries.

The document of financial impact forecast provides the expected own revenues and the costs charged to the municipal budget in terms of the municipal tasks implementation. Therefore, the forecast is an important strategic document prepared for the local development plan draft, it should be done well in 
advance and in cooperation with town planners and property appraisers as the persons responsible for estimating economic effects (Cymerman et al., 2008).

The problem of new residential areas excessive planning is widely discussed in Poland. Local development plans, in their current form, have a flawed functional structure, because they allocate excessively large areas for housing development, frequently exceeding by far the economic needs and possibilities of municipalities. In the entire country, as at the end of 2012, they allowed for the settlement of 62 million people (Report..., 2013). The question arises as to whether it can also apply to the area of Wrocław city.

The main purpose of the study is to analyse the economic effects resulting from the local development plans in force in several selected parts of Wrocław city, located within the geodesic precincts of Marszowice and Widawa. The research covers the costs of implementing local development plans, which exert financial impact on the budget of Wrocław Municipality as a result of the ongoing investment in these parts of the city.

\section{Methodology of of research and materials}

The realisation of the adopted research purpose required collecting information using the direct observation method. The information about the area covered by the study were collected from the available planning documents, i.e. local spatial development plans, the area base map and also maps from the Wrocław Spatial Information System. The identification of costs charged to the municipal budget was prepared based on the entries in local development plans. The study specifies costs of implementing local development plans taking into account the division, commonly found in the subject literature, into the following groups (Hełdak, 2013; Cymerman et al., 2008; Hełdak and Płuciennik, 2017):

- financial charges for negative consequences affecting real properties (compensations specified in Art. 36, item 1, point 1 and item 3 of the Spatial Planning and Management Act),

- financial charges connected with purchasing real property for the realisation of public goals,

- financial charges connected with the costs of infrastructure construction,

- financial charges connected with handling the investment process.

The analysis of costs charged to the municipality for the implementation of its own tasks related to purchasing real properties for the implementation of public goals required specifying the average transaction prices using the data from the Property Price and Value Register obtained from the Board of Geodesy, Cartography and Municipal Cadastre in Wrocław. The information about the existing transport connections and utilities network, resulting from the analysis of the area base map, allowed identifying the necessary infrastructure investments to be implemented. The cost of implementing planned construction works and infrastructure facilities (road construction, utilities network, greenery facilities and the construction of education establishments) was obtained from price registers of construction objects. The areas of the study are located within the city of Wrockaw. They are as follows:

- Local spatial development plan in the area of western part of Marszowice Malownicze III development area in Wrocław, the Resolution by the City Council of Wrocław dated November 20, 2003 (Official Journal of Lower Silesia Voivodship dated April 20, 2004, No. 71, item 1337);

- Local spatial development plan in the area of Kominiarska, Jubilerska and Sułowska Streets as well as the Wrockaw motorway ring road in Wrocław, the Resolution by the City Council of Wrocław No. LXI/1566/14 dated October 7, 2014 (Official Journal of Lower Silesia Voivodship from 2014, item 3223) (Fig. 1). 


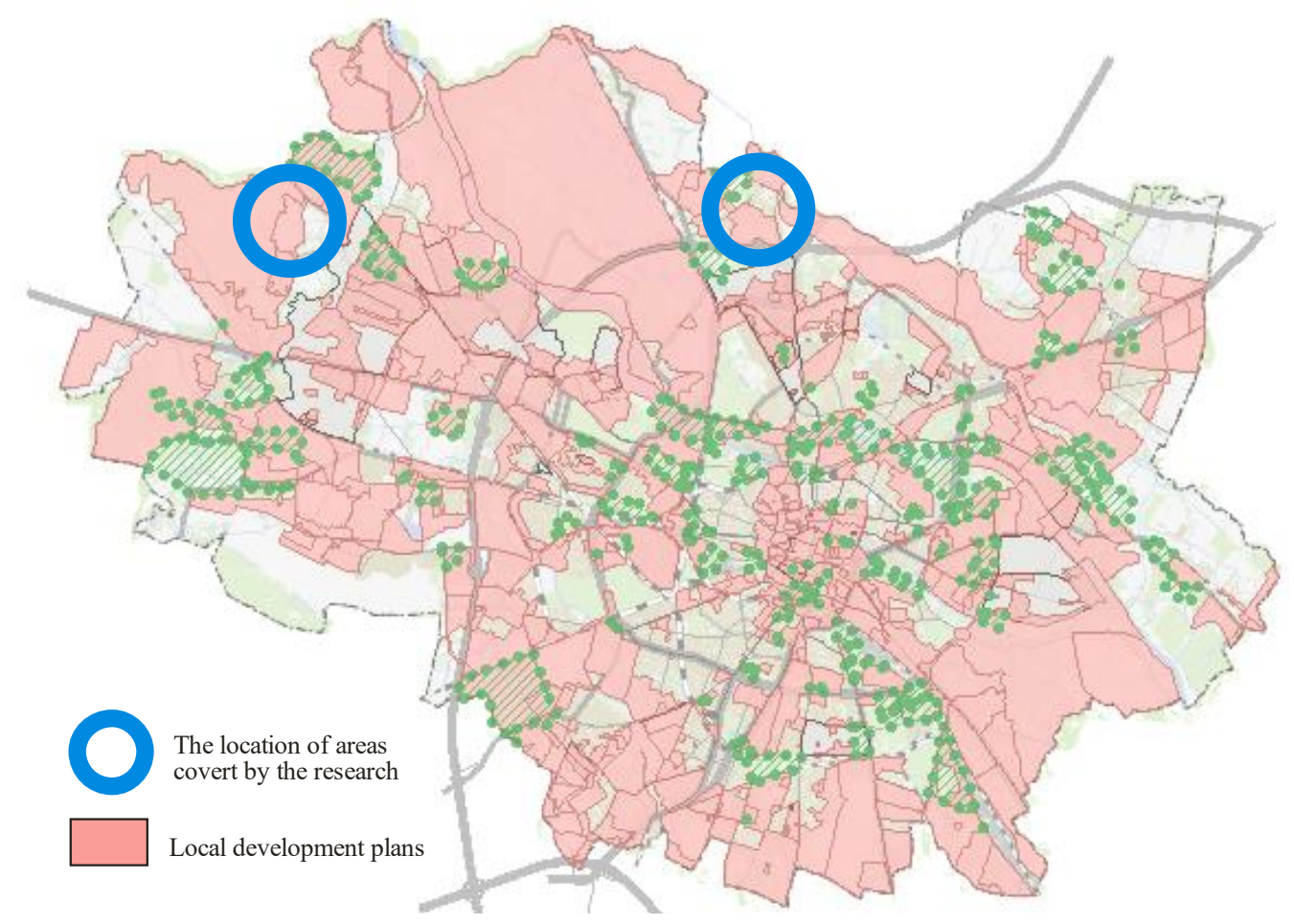

Fig. 1. The location of areas covered by the research regarding costs of local development plans implementation.

\section{Identification of the municipality own tasks}

Pursuant to the provisions of the local spatial development plan in the area of western part of Marszowice Malownicze III development area in Wroclaw the areas designated for the implementation of public goals are defined. These are the communication areas (L (local) class roads), marked on the plan with the following numbers and symbols: KL 1, KL 2, KL 3, KL 4. The identification of Wrocław Municipality obligations is preceded by the analysis of ownership status of the studied area. The areas of local roads are owned by Wrocław Municipality, therefore their buyout is not anticipated. Other areas of communication are the internal roads, i.e. the roads for which the owners of adjacent real properties (road co-owners) are responsible. Such solution reduces municipal costs, however, impedes the construction and maintenance of roads as the communication between the large number of the adjacent plots' co-owners regarding the construction and maintenance of the road is difficult.

Pursuant to the provisions of the local development plan in the area of the following streets: Kominiarska, Jubilerska and Sułowska as well as the Wrocław motorway ring road in Wrocław, the following areas are designated for the implementation of public goals: $1 \mathrm{KDZ}, 2 \mathrm{KDD} / 1,2 \mathrm{KDD} / 2$, $2 \mathrm{KDD} / 3,2 \mathrm{KDD} / 4,2 \mathrm{KDD} / 5,2 \mathrm{KDD} / 6,2 \mathrm{KDD} / 7,2 \mathrm{KDD} / 8,2 \mathrm{KDD} / 9,2 \mathrm{KDD} / 10,2 \mathrm{KDD} / 11$, $2 \mathrm{KDD} / 12,2 \mathrm{KDD} / 13,2 \mathrm{KDD} / 14,2 \mathrm{KDD} / 15,2 \mathrm{KDD} / 16$. Within the area covered by the local spatial development plans, the majority of real properties are owned by natural persons. Two of the plots located in the area covered by the plan to be developed for Widawa area are owned by the municipality. Road construction is planned on one of these plots (marked as $2 \mathrm{KDD} / 3$ in the local development plan), the other is intended for the service area $(9 \mathrm{U})$, the access street area $(2 \mathrm{KDD} / 14)$ and the green area (11Z/1). The construction of other public roads has to be preceded by the buyout to the municipal resources. A prerequisite for the construction of a public road is either the State Treasury or the local government unit ownership status of the land on which the discussed investment is to be carried out (Hełdak, 2013; Hełdak and Płuciennik, 2018). Similarly, the implementation of other municipal tasks requires, first of all, taking the land over to the municipal resources. The identification of the real properties area to be bought by Wrocław Municipality is presented in the table below (Table 1). 
Table 1

The area of land designated for roads to be bought out by Wrocław Municipality in the area of the following streets: Kominiarska, Jubilerska and Sułowska as well as the Wrocław motorway ring road.

\begin{tabular}{|c|l|c|}
\hline $\begin{array}{c}\text { Symbol in the local development } \\
\text { plan }\end{array}$ & \multicolumn{1}{|c|}{ Buyout purpose } & Buyout area [m2] \\
\hline $2 \mathrm{KDD} / 2$ & road widening & 340 \\
\hline $2 \mathrm{KDD} / 3$ & new road construction & 770 \\
\hline $2 \mathrm{KDD} / 4$ & intersection extension & 10 \\
\hline $2 \mathrm{KDD} / 5$ & road widening & 1385 \\
\hline $2 \mathrm{KDD} / 6$ & road widening & 260 \\
\hline $2 \mathrm{KDD} / 7$ & intersection extension & 10 \\
\hline $2 \mathrm{KDD} / 9$ & road widening & 1110 \\
\hline $2 \mathrm{KDD} / 10$ & intersection extension & 5 \\
\hline $2 \mathrm{KDD} / 11$ & new road construction & 5070 \\
\hline $2 \mathrm{KDD} / 12$ & new road construction & 2570 \\
\hline $2 \mathrm{KDD} / 13$ & road widening & 2735 \\
\hline $2 \mathrm{KDD} / 15$ & new road construction & 2605 \\
\hline $2 \mathrm{KDD} / 16$ & new road construction & 1915 \\
\hline & Total: & $\mathbf{1 8 7 8 5}$ \\
\hline
\end{tabular}

Source: authors' compilation

The conducted analyses also concerned the need for buying out land designated for public green areas. It was established that the obligation to buy out park greenery refers to $18425 \mathrm{~m}^{2}$ of land in the plan located within the area of Widawa (Tab. 2).

Table 2

The area of land designated for park greenery to be bought out by Wrocław Municipality in the area of the following streets: Kominiarska, Jubilerska and Sułowska as well as the Wrocław motorway ring road.

\begin{tabular}{|c|c|c|}
\hline $\begin{array}{c}\text { Symbol in the local development } \\
\text { plan }\end{array}$ & Buyout purpose & Buyout area $\left[\mathbf{m}^{\mathbf{2}}\right]$ \\
\hline $10 \mathrm{ZP}$ & park greenery & 14350 \\
\hline $11 \mathrm{Z} / 2$ & park greenery & 2215 \\
\hline $11 \mathrm{Z} / 3$ & park greenery & 1030 \\
\hline $11 \mathrm{Z} / 4$ & park greenery & 830 \\
\hline \multicolumn{2}{|r|}{ Total: } & 18425 \\
\hline
\end{tabular}

Source: authors' compilation

Financial impact related to the buyout of land for the implementation of public tasks

A municipality is obliged to buy out land designated for carrying out public goal investments according to the plan within Widawa geodetic area. As a result of implementing the provisions of the analysed plan, Wrocław Municipality will have to buy out land designated for public green areas, the areas intended for new access class communication routes and the land aimed at extending the existing communication routes indicated above.

To estimate the costs of buying out land designated for access roads in the local development plan, the average price of $1 \mathrm{~m}^{2}$ was adopted and calculated based on the real properties market analysis, referring to roads or intended for roads, in the amount of 180 PLN (42 EUR). The size of the area necessary to buy out is $18785 \mathrm{~m}^{2}$. The cost of buying out land designated in the local development plan for public roads was estimated at approx. 788970 EUR. 
To estimate the cost of buying out land designated for public green areas in the local development plan, the average price of agricultural property in the amount of 120 PLN (28 EUR) for $1 \mathrm{~m}^{2}$ was adopted. The total buyout area of the land designated for public green areas is $18425 \mathrm{~m}^{2}$. The cost of buying out land designated for green areas and park greenery in the local development plan was estimated at the amount of approx. 515900 EUR.

\section{The construction costs of technical infrastructure facilities within the scope of municipality own tasks \\ Water supply system}

The construction cost of water supply system was estimated based on the data from the Newsletter of Prices in the Construction Industry "SEKOCENBUD" part II Engineering objects published in the fourth quarter of 2018, issue number 70/2018 (1840). Projected technology: from PE-HD pipes $\varnothing 160$ $\mathrm{m}$, cast iron gate valves, underground fire hydrants, disinfection of pipelines, substrate for pipelines made of sand, layer thickness $10 \mathrm{~cm}$ (object number $5566 \mathrm{C}$ ). The network unit price (1 linear meter), taking into account the regional coefficient (for Lower Silesian Voivodship, the coefficient equals $0,952)$ is 360 PLN (84 EUR). According to the plan drawing in the local development plan, the length of water supply system is planned for $2500 \mathrm{~m}$ in the analysed area of Marszowice and $1550 \mathrm{~m}$ in Widawa region. The cost of water supply system construction was estimated at approx. 210000 EUR in Marszowice and 130200 EUR in Widawa area.

\section{Sanitary sewage system}

The construction cost of sanitary sewage system was estimated based on the data from the Newsletter of Prices in the Construction Industry "SEKOCENBUD". Projected technology: PVC pipes Ø 250 $\mathrm{mm}$, inspection chambers made of concrete coils $\varnothing 120 \mathrm{~mm}$, bedding material made of sand, layer thickness $15 \mathrm{~cm}$, tightness test (object number 5575). The network unit price (1 linear meter), taking into account the regional coefficient is 1200 PLN (280 EUR). According to the plan drawing in the local development plan, the length of sanitary sewage system is planned for $2500 \mathrm{~m}$ in the analysed area of Marszowice and $1550 \mathrm{~m}$ in Widawa region. The total cost of sanitary sewerage system construction will amount to approx. 700000 EUR within the scope of local development plan for Marszowice and 434000 EUR within the scope of the plan covering the part located in Widawa geodetic area.

\section{Access roads, passageways and paths for pedestrians and cyclists}

The cost of constructing municipal access roads was estimated based on the "Consolidated standards for the valuation of buildings and constructions" Issue No. 109. The investment implementation was estimated based on the object No. 72 (local roads and squares with cast asphalt surface) featuring the following parameters: mechanical trenching, $15 \mathrm{~cm}$ thick sand drainage layer, foundation of gravel concrete B-7.5 $18 \mathrm{~cm}$ thick, concrete curbs $44,72 \mathrm{~m} / 100 \mathrm{~m}^{2}$, asphalt concrete base $3 \mathrm{~cm}$ thick. The construction cost of $100 \mathrm{~m}^{2}$ of this surface type, taking into account the conversion factor for the region (the conversion coefficient range for Lower Silesia Voivodship $(0,77-0,88)$ was adopted as 0,80 equals PLN 18830 (4390 EUR). The size of the surface was calculated based on the measurement of the length of roads from the plan drawing (length of roads $-1550 \mathrm{~m}$ ) and the adopted road width. In accordance with the provisions of the Regulation on technical conditions to be met by public roads and their location ${ }^{1}$, the width of access road lane in built-up areas should range between $2,25 \mathrm{~m}$ and $2,5 \mathrm{~m}$. The adopted width of the road lane is $2,5 \mathrm{~m}$, therefore the road width will be $5 \mathrm{~m}$. The surface of $3500 \mathrm{~m}^{2}$ (Marszowice) and $7750 \mathrm{~m}^{2}$ (Widawa) was intended for hardening. The total construction cost of municipal access roads was estimated at 493875 EUR.

The construction costs of passageways and paths for pedestrians and cyclists were estimated based on the data from the Newsletter of Prices in the Construction Industry "SEKOCENBUD". In the forecast, the price of $1 \mathrm{~m}^{2}$ surface construction was adopted as $1 \mathrm{~m}^{2}$ pavement surface (passageway) of the path for pedestrians and cyclists "D" class in the urban area (object No. 5335), which taking into account the regional coefficient is PLN 185 (43 EUR). The size of the surface was calculated based on the plan drawings (length of passageways $-1000 \mathrm{~m}$ and $1675 \mathrm{~m}$ ) and the adopted passageway width, that according to legal provisions (Regulation) should not be less than 2,5 $\mathrm{m}$ regarding bike paths which can also be used by pedestrians and not less than $2 \mathrm{~m}$ in the case of pavements by the roads. It was adopted that a path for pedestrians and cyclists will be $3 \mathrm{~m}$ wide and the width of a pavement $-2 \mathrm{~m}$,

\footnotetext{
${ }^{1} \S 15$ Regulation of the Minister of Transport and Maritime Economy of March 2, 1999 on technical conditions to be met by public roads and their location (Official Journal from 1999, No. 43, item 430).
} 
thus the surface of passageways was established at $2000 \mathrm{~m}^{2}$ (Marszowice) and $3870 \mathrm{~m}^{2}$ (Widawa). The total construction cost of passageways and paths for pedestrians and cyclists was estimated at approx. 86000 EUR i 166410 EUR

\section{Financial impact related to setting up public green areas}

The municipality is also responsible for setting up areas designated in the local spatial development plan for the purposes of public greenery. The analysed local development plan in the area of Kominiarska, Jubilerska and Sułowska Streets as well as the Wrocław motorway ring road in Wrocław allocates four areas for greenery purposes (marked in the plan with the following symbols: 11Z/1, $11 \mathrm{Z} / 2,11 \mathrm{Z} / 3,11 \mathrm{Z} / 4)$ and one area aimed at park greenery (10ZP). In the case of green areas, it was adopted that trees will be planted along the planned rows of trees and a lawn will be set up. The average tender price in Wrocław of PLN 900 (210 EUR) was adopted as the cost of planting one tree. The price includes the cost of purchase, planting and three-year care used for planting rows of tree saplings approx. 2,5 m high with trunk circumference of $16-18 \mathrm{~cm}$. The number of trees was determined based on the planned length of the rows of trees and the assumption that they will be planted 8 meters apart. Therefore, as a result of implementing the plan provisions, it will be necessary to plant 63 trees. The cost of planting was estimated at $63 \times 210=13230$ EUR.

The cost of planting a lawn was estimated based on the data from the Newsletter of Prices in the Construction Industry "SEKOCENBUD". The price of $1 \mathrm{~m}^{2}$ of lawn surface in flat area (object No. 8392, taking into account the regional coefficient, is PLN 20 (4,70 EUR). The above price covers preparing the ground for the lawn and unfolding the lawn from a roll. The estimated costs of setting up a lawn amount to PLN 39442 EUR. The total cost of arranging public greenery marked in the plan with the following symbols: 11Z/1, 11Z/2, 11Z/3, 11Z/4 was estimated at approx. 52672 EUR.

In the area designated for park greenery, marked in the local development plan with the symbol 10ZP, the construction of a rectangular playground was adopted, presenting the following dimensions $20 \times 25$ $\mathrm{m}$ and covering the area of $500 \mathrm{~m}^{2}$. It was assumed that the playground will be situated along the path for pedestrians and cyclists. The cost of the playground construction was estimated based on the data from the Newsletter of Prices in the Construction Industry "SEKOCENBUD" - object No. 8393 children playground. The price of $1 \mathrm{~m}^{2}$ of the playground surface, including the regional coefficient, is PLN 185 (EUR 43). The price covers the play equipment available at the playground such as e.g. a swing, a slide, etc. The total cost of arranging park greenery area, marked in the local development plan with the symbol 10ZP, was estimated at approx. 21500 EUR.

\section{Discussion}

The research estimates budget expenditure of Wrockaw Municipality related to the implementation of decisions resulting from the analysed local spatial development plans. The costs were not broken down into particular years of the forecast due to the difficulty in determining the duration of the investment implementation. The selected construction materials used in the implementation of infrastructure and communication networks have impact on the forecasted costs. The local development plan provisions lack the specification of investment parameters, therefore for the needs of the study the data included in the "Consolidated standards for the valuation of buildings and constructions" were adopted. The list of expenditure is presented in Table 3.

Table 3

The list of costs of the analysed local development plans implementation

\begin{tabular}{|c|c|c|}
\hline Specification & Marszowice [EUR] & Widawa [EUR] \\
\hline $\begin{array}{l}\text { Buyout of real properties intended for the implementation of } \\
\text { public goals }\end{array}$ & none & 788970 \\
\hline Construction of municipal roads & 153650 & 340225 \\
\hline Construction of paths for pedestrians and cyclists & 86000 & 166410 \\
\hline Construction of sanitary sewage system & 700000 & 434000 \\
\hline Construction of water supply system & 210000 & 130200 \\
\hline Construction of a street lighting network & not estimated & not estimated \\
\hline Financial impact related to setting up public green areas & none & 74172 \\
\hline TOTAL: & 1149650 & 1933977 \\
\hline
\end{tabular}

Source: authors' compilation

The analysis showed that the construction of communication passageways has a large financial impact on the municipal budget and these costs were estimated at EUR 153650 and EUR 340225 
respectively (approx. 17\% of the total expenditure in Widawa). The total cost of technical infrastructure network construction was estimated as: 910000 EUR (Marszowice) and 564200 EUR (Widawa), whereas the cost of sanitary sewerage system construction definitely exceeds that of water supply system implementation.

Recently, the regulations regarding co-financing costs, associated with infrastructure development, resulting from the adoption of the local spatial development plan for revitalization were introduced in Poland. This fee is a completely new solution and, so far, has been rarely used. Investors, including developers, often do not incur any costs of expanding technical infrastructure facilities and they never cover the costs of social infrastructure facilities. The construction of education, culture, sport and recreation establishments at the local level is charged to the municipal budget (Hełdak, Płuciennik 2017).

\section{Conclusions}

The presentation of legal and theoretical determinants for preparing the financial impact forecast associated with the adoption of the local development plan, as well as the prepared cost analysis having impact on the municipal budget and related to the implementation of the selected local spatial development plans, allowed formulating the following conclusions:

1. The estimated costs of preparing construction sites constitute a major challenge for the municipal budget. New construction sites require significant financial outlays to allow their development and subsequently to organize services for the local population.

2. The ownership situation of real properties covered by the local development plan is of significant importance in the context of the need to buy out land for the implementation of the municipality own tasks.

3. Another component of municipal policy included in the local development plan provisions is to avoid public roads planning (the plan in the area of Marszowice estate). Instead of offering public communication, the communication accessibility is planned through internal roads, the implementation of which does not have financial impact on the municipality and the owners of adjacent land.

4. Based on the example of selected local development plans it is noticeable that the level of costs to be invested in the local development plan implementation depends not only on the area covered by the plan, but also on the level of investment and development of this area. For this reason, e.g. in Germany, spatial development of a given location is possible only within the capacity of existing infrastructure network or provided it is properly expanded (Czaja-Hliniak, 2010).

\section{References:}

1. Czaja-Hliniak I. (2010) Postulaty zmian regulacji opłat adiacenckich i opłaty planistycznej w: Opłaty samorządowe w Polsce - problemy praktyczne [Postulates for changes in the adjacent fees and planning fees in: Local government fees in Poland - practical problems], ed. Liszewski G., Białystok. (In Polish)

2. Cymerman R., Bajerowski T., Kryszk H. (2008) Prognoza skutków finansowych uchwalenia miejscowego planu zagospodarowania przestrzennego, [The forecast of financial impacts resulting from the adoption of the local spatial development plan] EDUCATERRA, Olsztyn. (In Polish)

3. Hełdak M., Raszka B. (2013) Evaluation of the local spatial policy in Poland used in the Wroclaw poviat with regard to sustainable development", Polish Journal of Environmental Studies, Vol. 22, No. 2 (2013), 395-402.

4. Hełdak M., 2013. Prognozowanie finansowych skutków uchwalenia planu miejscowego [Forecasting the financial impacts of adopting a local development plan], Texter, Warsaw. (In Polish)

5. Hełdak M., Raszka B., Szczepański J. (2016) Design of Ground Surface Sealing in The Spatial Policy of Communes, World Multidisciplinary Civil Engineering-Architecture-Urban Planning Symposium 2016, WMCAUS Praha 2016, Procedia Engineering, 161 (2016), pp. 1367-1372.

6. Hełdak M., Pluciennik M., (2017): Costs of Urbanisation in Poland, Based on the Example of Wrocław. IOP Conference Series: Materials Science and Engineering; ISSN 1757-8981 [p]; ISSN 1757-899X [e]; 2017; Vol. 245, 032052, pp. 1-7. DOI: 10.1088/1757-899X/245/7/072003.

7. Hełdak M. Płuciennik M. (2018) Ekonomiczne aspekty decyzji planistycznych na przykładzie miasta Wrocławia [Economic aspects of planning decisions - the case of Wroclaw city]. Prace Naukowe Uniwersytetu Ekonomicznego we Wrocławiu. Gospodarka przestrzenna - stan obecny i wyzwania przyszłości [Research Studies of Wrocław University of Economics. Spatial economy - current status and future challenges]; ISSN 1899-3192 [p]; ISSN 2392-0041 [e]; ISBN 978-83-7695-687-9; Wrocław : Wrocław University of Economics Press, 2018; No. 504 pp. 64-71. DOI: 10.15611/pn.2018.504.06. (In Polish) 
8. Local spatial development plan in the area of western part of Marszowice Malownicze III development area in Wrocław, the Resolution by the City Council of Wrocław dated November 20, 2003 (Official Journal of Lower Silesia Voivodship dated April 20, 2004, No. 71, item 1337).

9. Local spatial development plan in the area of Kominiarska, Jubilerska and Sułowska Streets as well as the Wrocław motorway ring road in Wrocław, the Resolution by the City Council of Wrocław No. LXI/1566/14 dated October 7, 2014 (Official Journal of Lower Silesia Voivodship from 2014, item 3223).

10. Newsletter of Prices in the Construction Industry "SEKOCENBUD" (2018), 70/2018 (1840). Ośrodek Wdrożeń Ekonomiczno - Organizacyjnych Budownictwa "PROMOCJA" Sp. z o. o.,

11. Przybyła K., Kachniarz M., Kulczyk-Dynowska A. (2014) Quality of Life in the Regional Capitals of Poland, Journal of Economic Issues, Volume 48, Number 1 / March 2014, pp. 181-196, 10.2753/JEI00213624480109.

12. Raport o ekonomicznych stratach i społecznych kosztach niekontrolowanej urbanizacji w Polsce. Instytut Geografii i Przestrzennego Zagospodarowania. Fundacja Rozwoju Demokracji Lokalnej [The report on economic losses and social costs of uncontrolled urbanization in Poland. Institute of Geography and Spatial Organization. Foundation for the Development of Local Democracy], Warsaw, 2013. (In Polish)

13. Regulation of the Minister of Transport and Maritime Economy of March 2, 1999, on technical conditions to be met by public roads and their location (Official Journal from 1999 No. 43, item 430).

14. The Act dated March 8, 1990, on Municipal Self-Government (consolidated text Official Journal from 2018, item 994, as amended).

Maria Hełdak, Associate Professor, director of the Faculty of Geodetic Agricultural Facilities and Real Estate Economy of the Department of Spatial Economy at the University of Environmental and Life Sciences in Wrocław (Poland), e-mail: maria.heldak@upwr.edu.pl

Maria Hełdak's scientific interests revolve around real estate economy and real estate evaluation, spatial economy, the evaluation of the financial and environmental consequences of implementing local spatial development plans and spatial policy.

Katarzyna Przybyla, Dr, lecturer of the Department of Spatial Economy at the University of Environmental and Life Sciences in Wrocław (Poland), e-mail: katarzyna.przybyla@upwr.edu.pl

Katarzyna Przybyła's scientific interests revolve around spatial economy, spatial policy, functioning of cities and aspects of administrative reform in Poland. 